\title{
Praktyczne możliwości edukacji ekologicznej w kontekście programu "badacze przyrody"
}

\section{Podstawy edukacji ekologicznej}

Edukacja z zakresu przyrody jest różnorodnie nazywana jako - ekologiczna, przyrodnicza, środowiskowa, leśno-przyrodnicza, czy edukacja dla zrównoważonego rozwoju. Ma na celu pobudzenie szacunku do przyrody i wykształcenia umiejętności dostrzegania piękna środowiska naturalnego. W rozumieniu potocznym osiąga się cele takiej edukacji poprzez wszelką formę działalności skierowanej do społeczeństwa, ze szczególnym uwzględnieniem dzieci i młodzieży. Mnogość określeń tej edukacji wynika z kilku przesłanek. Pierwszą jest duża ilość synonimów dla określenia „przyroda”, co pozwala na wieloznaczności w nazywaniu działań edukacyjnych na tym polu. Również drobne różnice pomiędzy tymi określeniami nie są wystarczająco ostro sprecyzowane, a co za tym idzie - cel edukacji nie zawsze jest rozumiany. Đrzeci czynnik, z powodu którego spotykamy w literaturze wiele określeń, wynika $z$ założeń przedstawionych w przepisach prawnych. Jedną z ostatnich różnic jest sposób przekazywania wiedzy oraz miejsca, w których edukacja się odbywa.

W tym kontekście proponuję podzielić sposoby edukacji z zakresu przyrody na trzy podstawowe typy - edukacja ekologiczna szkolna, edukacja ekologiczna pozaszkolna oraz edukacja leśno-przyrodnicza. Podział ten wynika z dwóch podstawowych różnic. Pierwszą jest kwestia podziału na zakres tematyczny, który wskazuje na edukację leśno-przyrodniczą i edukację ekologiczną ${ }^{1}$. Druga - wynika z różnic w przepisach prawnych i miejsca, w których ta edukacja jest realizowana, przez co uzyskujemy edukację formalną - szkolną, oraz pozaszkolną - nieformalną.

Przykładowymi innymi określeniami, według tego podziału, będą: edukacja środowiskowa, edukacja przyrodnicza, edukacja biologiczna, czy edukacja dla zrównoważonego rozwoju. 
W niniejszym artykule przedstawiona zostanie edukacja ekologiczna nieformalna, a więc pozaszkolna. Można przyjąć, że edukacja ta opiera się na dokumentach krajowych i międzynarodowych ${ }^{2}$. I tak, krajowymi dokumentami będą: Do zrównoważonego rozwoju. Narodowa Strategia Edukacji Ekologicznej Warszawa 2001, Prawo Ochrony Srodowiska z dnia 27 kwietnia 2001 roku, art. 77, Polityka Ekologiczna Państwa na lata 2007-2010 z uwzględnieniem perspektywy na lata 2011-2014, a także Konstytucja Rzeczypospolitej Polskiej - art. 5 i 74. Dokumentami międzynarodowymi będą natomiast: Agenda 21, Ramowa konwencja Narodów Zjednoczonych w sprawie Zmian Klimatu, Konwencja o ochronie różnorodności biologicznej, Dekada edukacji dla zrównoważonego rozwoju 01.01.2005, oraz Strategia Europejskiej Komisji Gospodarczej ONZ dotycząca edukacji dla zrównoważonego rozwoju Wilno 2005 pod patronatem UNESCO.

Ośrodki odpowiedzialne za edukację ekologiczną występują zarówno na szczeblu centralnym (Sejm i Senat), jak i na szczeblu samorządowym - ośrodki władzy: województwa, samorządu i powiatu. Działania edukacyjne inicjowane są również przy muzeach przyrodniczych, kościołach i związkach wyznaniowych. Edukację ekologiczną organizują również różnego typu organizacje społeczne. Bardzo dobra forma działan lokalnych jest właczenie młodzieży i dorostych do podejmowania projektów edukacyjnych ${ }^{3}$. Ważną rolę w procesie edukacji odgrywa także rodzina. Nie można zapominać o roli ośrodków masowego przekazu oraz animatorów aktywnego wypoczynku i turystyki. We wszystkich wymienionych wyżej ośrodkach edukacja ekologiczna jest uzależniona od ich rodzaju i możliwości realizowania stawianych zadań.

Cele edukacji ekologicznej są określone w Narodowej Strategii Ekologicznej Państwa oraz w Polityce Ekologicznej Państwa. Natomiast formy przekazu stosuje się najczęściej adekwatnie do możliwości danego ośrodka. Najbardziej powszechne zdają się być wszelkiego typu bierne formy edukacji, takie jak tablice informacyjne, foldery, punkty edukacyjne, ścieżki edukacyjne. Do aktywnych form zaliczyć można prowadzone lekcje. Odbywają się one najczęściej na terenach zielonych lub

2 Dla skutecznej edukacji ekologicznej warto wykorzystywać przepisy prawne będące podstawą edukacji ekologicznej szkolnej oraz edukacji leśno-przyrodniczej. Zatem, będą to odpowiednio: rozporządzenie ministra edukacji narodowej i sportu $\mathrm{z}$ dnia $26.02 .2002 \mathrm{r}$. w sprawie podstawy programowej wychowania przedszkolnego oraz kształcenia ogólnego w poszczególnych typach szkół; Zarządzenie nr 57 Dyrektora Generalnego Lasów Państwowych z 9.05.2003 r. w sprawie wytycznych prowadzenia edukacji leśnej spoleczeństwa w Lasach Państwowych; ustawa o lasach $z$ dnia 28.09.1991 r., art. 33 ust. 1, oraz porozumienie międzynarodowe - Porozumienie Ministrów Edukacji Narodowej oraz Ochrony Środowiska, Zasobów Naturalnych i Leśnictwa $\mathrm{z}$ dn. 19.04.1995 r.

3 Por. D. CichY, Świadomość ekologiczna młodzieży szkolnej, w: (red. J. M. Dołęga, J. Sandner), Swiadomość i edukacja ekologiczna, Warszawa 1998, s. 9. 
w lesie. Moga mieć bardzo różna organizację, w zależności od postawionych celów. Obszarem, na którym sa prowadzone zajęcia może być na przykład ogród dydaktyczny, ulica, park miejski, zakład przemystowy. Podobnie czas trwania, zaangazowany personel, sprzęt i liczba uczestników mogą się zmieniać w bardzo szerokich granicach. Okazuje się, że przydatne dydaktycznie moga być obszary skrajnie zdegradowane, jak $i$ bardzo zbliżone do naturalnych ${ }^{4}$. Coraz popularniejsze są także lekcje w formacie e-learnigu, czyli edukacja przez Internet.

\section{Warunki zespołu pałacowo-parkowego Muzeum Pałac w Wilanowie dla edukacji ekologicznej}

Muzeum Pałac w Wilanowie posiada doskonałe warunki do realizacji działań edukacyjnych, w tym także edukacji ekologicznej. Park wilanowski usytuowany na terenie Muzeum, sprzyja inicjowanym wszelkim przedsięwzięciom edukacyjnym. Park Wilanowski położony jest na terenie o powierzchni 45 hektarów. Powierzchnia ta umożliwia skuteczną i praktyczną edukację ekologiczną najmłodszych uczestników różnorakich zajęć. \eren ten wzbudza zainteresowanie dzięki ciekawemu położeniu geologicznemu ${ }^{5}$. Pałac wraz z Parkiem usytuowany jest na krawędzi niższego tarasu nadzalewowego ${ }^{6}$. Dzięki temu położeniu na terenie Wilanowa dominują gleby rzeczne. Warunki geologiczne są wzbogacone również przez powierzchniowe cieki wodne. Przez teren Parku przepływa historyczny potok Warszawy, tak zwany Potok Służewiecki. Na terenie Parku znajduje się również Jezioro Wilanowskie. Jezioro to jest dawnym starorzeczem Wisły, a obecnie jest również jeziorem przepływowym - czym wyróżnia się na tle innych zbiorników wodnych w Warszawie. W Parku można również odnaleźć staw, który w czasach króla Jana III Sobieskiego prawdopodobnie pełnil funkcje użytkowe.

Na terenie Parku występuje bogata wielowarstwowa roślinność. Dostrzec na tym terenie możemy wiele różnorodnych siedlisk, bogatą faunę wilanowskiej przyrody. Nad wodami w parku występuje roślinność szuwarowa i wodna, dostrzec można również fragmenty lasów łęgowych. Znaleźć można także potencjalne siedlisko dąbrowy świetlistej, siedlisko grądowe oraz liczne okazy drzew będących pomnikami przyrody. Cały zespół roślinny pełni różnorodne funkcje w ekosystemie Parku. Flora Parku przechwytuje część zanieczyszczeń pochodzących z terenów przyległych do pałacowo-ogrodowych założeń przestrzen-

4 Por. W. Borkowski, Terenowa edukacja ekologiczna, (red. J. Leśniewska, J. W. Czaroszewski), Edukacja w naturze, czyli jak pokochać, poznać, zrozumieć i chronić przyrodę. Chrześcijaństwo i edukacja ekologiczna, t. 2, Warszawa 2002, s. 41.

5 Więcej na ten temat zobacz w opracowaniu ekofizjograficznym dla studium uwarunkowań i kierunków zagospodarowania przestrzennego miasta stołecznego Warszawy.

6 Jest to tak zwany taras praski. 
nych. Przede wszystkim, odprowadza i filtruje zanieczyszczenia powietrza. Roślinność występująca przy potoku Służewieckim stanowi również naturalne filtry dla zanieczyszczonej wody. Inna funkcja Parku i jego otoczenia jest niezwykle istotna dla terenu zurbanizowanego. Obszar ten tworzy mikroklimat wilanowski, który utrzymuje większą wilgotność powietrza. Warunki przyrodnicze sprzyjają wymianie powietrza powodując wzbogacenie powietrza w tlen.

Osoby zwiedzające Park, przez obserwacje ptaków najszybciej dostrzegają bogatą faunę . Ptaki to grupa zwierząt najlepiej rozpoznawalnych przez osoby odwiedzające Wilanów. Obecność poszczególnych gatunków ptaków zależy od miejsca w ogrodzie, a więc od stopnia zróżnicowania siedliska oraz od wieku drzewostanu. Występują tu bowiem zespoły ptaków leśno-parkowych, reprezentowane przez dzięcioły, oraz zróżnicowane gatunkowo ptaki śpiewające, gniazdujące zarówno na drzewach, jak i w warstwie podszytu. Obfity zespól ptaków wodno-błotnych prezentują m.in. perkozy, kaczki, chruściele, mewy, rybitwy, oraz drobne ptaki zasiedlające szuwary. Rzadko spotykaną grupę, lecz równie ciekawą, stanowią ptaki drapieżne, do których należą błotniaki stawowe, krogulce, myszołowy zwyczajne oraz wyjątkowo zalatujące tu sokoły wędrowne.

Prócz ptaków reprezentujących faunę Wilanowa występują także ssaki. Bogaty zespół reprezentują gryzonie, wśród których występują jeże, wiewiórki, czy piżmaki. Natomiast drapieżniki reprezentowane są przez norki, kuny oraz wydry. Aktywne nad jeziorem są także nietoperze. Podczas ciepłych miesięcy pojawiają się płazy i gady.

W parku tym spacerowicze mogą obserwować procesy przyrodnicze zachodzące na obszarze Muzeum. Đeren ten ukazać może nie tylko różnorodność świata biotycznego oraz abiotycznego, ale również różnice w architekturze przestrzennej tego terenu. Ogród wilanowski jest typowym przykładem założenia, rozwijającego się w ciagu wieków zarówno w zakresie terytorialnym, jak i formalnym. Pierwotny, szczuply stosunkowo ogród z końca XVII w., wiq̨żący się ściśle swoim układem z pałacem, rozwija się w ciagu XVIII i XIX w., wchłaniając coraz to nowe sąsiednie obszary, podlegajac jednocześnie mniej lub bardziej petnym przemianom stylowym. ${ }^{8}$ Można tu wydzielić ogrody reprezentujące różne style historyczne: dwupoziomowy ogród barokowy, neorenesansowy ogródek różany, angielski ogród krajobrazowy oraz park krajobrazowy angielsko-chiński.

7 Według inwentaryzacji wykonanych na zlecenie Muzeum Pałac w Wilanowie, na terenie parku obserwowano ponad 100 gatunków ptaków.

8 G. CIoŁek, Ogród w Wilanowie. Badania izagadnienia konserwatorskie, Biuletyn Historii Sztuki i Kultury, 1-2(1947), s. 92. 


\section{3. „Badacze przyrody” w Muzeum Pałac w Wilanowie}

Program edukacyjny o nazwie „badacze przyrody” zrealizowany został w Parku Wilanowskim Muzeum Pałac w Wilanowie, przy współpracy Uniwersytetu Kardynała Stefana Wyszyńskiego. Program skierowany został przede wszystkim do dzieci oraz ich rodziców. Spotkania odbywały się dziewięciokrotnie w każdy kolejny weekend kwietnia i maja. Spotkania rozpoczynały się o $10.00 \mathrm{i}$ trwały po cztery godziny.

\subsection{Założenia i cel programu}

Celem tego programu była poprawa świadomości ekologicznej osób odwiedzających Muzeum Pałac w Wilanowie. Rozpowszechniano zatem wśród uczestników spotkań wiedzę o świecie przyrody i procesach w nim zachodzącym. Podstawowym jednak celem programu było zwrócenie uwagi na wyjątkowe otoczenie pałacu. Biorąc pod uwagę położenie parku, który znajduje się niemalże w centrum europejskiej stolicy, jest jeszcze bardziej interesujące. Opisane już wcześniej warunki zespołu pałacowo-parkowego są bardzo dobre do prowadzenia edukacji w naturze, która to jest najlepszą formą edukacji. Niezwykle ważne jest pokazywanie dzieciom przyrody „od środka”. Dotknięcie kory drzewa, przerysowanie listka, obserwacja motyla przez lupe, szukanie śladów i tropów zwierząt, obserwacja poprzez zabawe, stanowia najlepsza i najtańsza pomoc dydaktyczna. Właśnie dzię̧i takim doświadczeniom, dzieci będa mogły zrozumieć otaczająca je przyrodę, zachwycić się muchomorem czerwonym, którego właśnie zjada ślimak, czy mieniącym się $w$ słoncu zielono-blękitnym chitynowym pancerzykiem $\dot{z} u k a^{9}$. 冈aka aktywizująca forma edukacji zapewnia najlepszy sposób dotarcia do najmłodszych uczestników procesu edukacji. Zatem przyroda, która otacza park wilanowski, jest najlepszym i najtańszym środkiem dydaktycznym w doskonaleniu świadomości ekologicznej.

Znaczenie tego miejsca jest istotne nie tylko ze względu na różnorodność biologiczną, ale także - na cały wymiar historyczny i kulturowy. \rzystuletnia tradycja miejsca jest również ważna w pełnym i całościowym procesie edukacji. Przyroda na terenie Wilanowa została objęta działalnością człowieka. Nie znajduje się ona w stanie naturalnym, lecz zagospodarowanym przez człowieka. W wyniku tych działań przybrała ona formę parku, w którym były realizowane różne założenia przestrzenne. Zorganizowana przyroda przybrała założenia zarówno włoskich, czy angielskich stylów zakładania ogrodów. \ak postrzegana przyroda jest zatem cenną również ze względu na dziedzictwo kulturowe.

$9 \quad$ K. Fidler, Czym jest edukacja w przyrodzie? : (red. J. Leśniewska, J. W. Czaroszewski), Edukacja w naturze, czyli jak pokochać, poznać, zrozumiec i chronić przyrodę. Chrześctjaństwo i edukacja ekologiczna, t.2, Warszawa 2002, s. 35. 
Przyroda jest naszym dziedzictwem narodowym, a edukacja w przyrodzie, jest jedyna szansa dla przyszłych pokoleń, aby mogły się z niq jeszcze cieszyć i również o nią dbać, kochać ją i szanować ${ }^{10}$. Dlatego też równie ważnym celem realizowanego programu było zwrócenie uwagi na dziedzictwo kulturowe tego miejsca. Zatem została podjęta próba edukacji całościowej z uwzględnieniem tożsamości miejsca i wszystkich przesłanek historycznych Wilanowa.

Program edukacyjny był skierowany przede wszystkim do najmłodszych osób. Uwzględniono także potrzeby opiekunów, z którymi dzieci miały przychodzić, a byli nie tylko rodzice, ale też dziadkowie. Zatem przedział wiekowy wszystkich uczestników spotkań był bardzo duży. Dlatego przewidziano szereg zabaw, które były zróżnicowane w poziomie trudności oraz tematyce. Również program spotkań przewidywał różne formy edukacji. Były zarówno zabawy pod namiotem dla najmłodszych uczestników oraz organizowane wycieczki po parku z przewodnikami dla osób starszych.

Głównym założeniem programu był cykl dziewięciu spotkań tworzących całość. Każde $z$ nich miało odmienny motyw przewodni. Natomiast kolejność wszystkich spotkań musiała uwzględniać również aktualny stan zjawisk przyrodniczych zachodzących w parku. Zadbano, by tematyka poszczególnych zajęć była adekwatna do procesów przyrodniczych zachodzących w parku. W rezultacie zaplanowano dziewięć spotkań zatytułowanych odpowiednio: zwiastuny wiosny, zwierzyniec, "ptasiowo"11, owady, motyle, drzewa i krzewy, kwiaty, woda, finał. Istotnym czynnikiem było utworzenie programu o przyrodzie, która występuje w Parku Wilanowskim. Zatem wszystkie gatunki i odmiany fauny oraz flory omawiane podczas programu edukacyjnego występowały na miejscu zajęć. 囚ak samo w przypadku abiotycznej części przyrody. Wspominanie położenie geologiczne oraz układ wodny odnosił się tylko do obszaru Wilanowa.

Jednym z założeń realizacji programu był także udział studentów II roku ochrony środowiska UKSW. Prowadzili oni zajęcia w Wilanowie w ramach swoich zajęć terenowych z edukacji ekologicznej. Służyli swoją wiedzą i byli pomocą dla dzieci w rozwiązywaniu wszystkich zadań.

\subsection{Realizacja}

Realizacja programu przypadła na dwa wiosenne miesiące, a więc kwiecień i maj. Podczas tych dwóch miesięcy w świecie przyrody zachodzi bardzo dużo przemian. Dzięki temu w krótkim czasie można zaobserwować gołym okiem, jak świat budzi się po zimowym okresie zastoju. Dostrzec w parku można wiosen-

\footnotetext{
ఐamże, s. 36.

11 Ptasiowo - jest także nazwą jednej z lekcji muzealnych realizowanych przez dział edukacji w Muzeum Pałac w Wilanowie. Lekcja ta jest skierowana do uczniów klasy 0-3 szkół podstawowych, na której dzieci poznają ptaki.
} 
ne kwiaty, zwierzęta łączące się w pary przed okresem rozrodu, a także zmianę poziomu wody w potoku i w jeziorze. Dlatego termin przeprowadzenia działań edukacyjnych przypadł właśnie na te dwa miesiące.

Program edukacyjny był realizowany tylko dwa dni w tygodniu, a mianowicie w soboty i w niedziele. Pozwoliło to wszystkim zainteresowanym na swobodne dotarcie na zajęcia. Dzięki weekendom także na zajęciach mogły być osoby, które przyjeżdżały do Wilanowa na jednodniową wycieczką do Warszawy. Każdego dnia program przewidziano na cztery cztery godziny. Dzięki temu sami zainteresowani mogli sobie wybrać porę przybycia na zajęcia.

Pierwsze spotkanie poświęcone było zagadnieniom wiosennym. Dzieci mogły zaobserwować i poznać procesy zachodzące w ekosystemie na początku wiosny. Również wskazywane były uczestnikom spotkania typowe oznaki wiosny - na przykład typowe wiosenne kwiaty, takie jak złoć żółta i ziarnopłon wiosenny. Następny temat zajęć był poświęcony zwierzętom, głównie ssakom, płazom i gadom. Dzieci mogły dowiedzieć się wielu ciekawostek o życiu niektórych mieszkańców Parku Wilanowskiego. Zainteresowane osoby poznawały także tryb życia wydry, która jest zwierzęciem wpisanym w historię Wilanowa z czasów Jana III Sobieskiego. 『rzeci weekend poświęcony został ptakom. Są to zwierzęta najliczniej pojawiające się w Parku Wilanowskim. Dzieci uczyły się rozpoznawać skrzydlatych mieszkańców po upierzeniu oraz po głosie. Z pewnością największą atrakcją spotkania był prawdziwy sokół - raróg górski. Kolejne dwa spotkania poświęcone zostały odpowiednio - owadom i motylom. Wszystkie dzieci, prócz zdobycia umiejętności ich rozpoznawania, uczyły się cyklu ich życia, a także funkcji pełnionych przez nie w ekosystemie. Szóste spotkanie odbyło się pod hasłem: drzewa i krzewy. Uczestnicy spotkania mogli nauczyć się rozpoznawania typowych gatunków drzew po liściach, zobaczyć pomnikowe okazy drzew oraz obserwować rodzime i obcego pochodzenia ich gatunki. Wszyscy chętni mogli także podziwiać rosnące $w$ parku krzewy oraz dowiedzieć się, jakimi owocami odżywiają się poszczególne zwierzęta. Siódme spotkanie poświęcone zostało kwiatom rosnącym w ogrodzie barokowym. Dzieci mogły dzięki temu spotkaniu dowiedzieć się, według jakich kryteriów dobiera się kwiaty do ogrodu. Ciekawość wzbudziła także symbolika poszczególnych odmian, a także kolorów kwiatów, którymi wypełnione są partery barokowego ogrodu. Przedostatnie spotkanie dotyczyło wody. Dzieci poznawały zasady, według których woda krąży w przyrodzie, także znaczenie, jakie woda ma dla wszystkich organizmów żywych. Wszyscy zainteresowani mogli obserwować również, skutki jakie może mieć niedobór czy zanieczyszczenie wody w ekosystemie. Ostatnie dziewiąte i zarazem finałowe spotkanie miało na celu podsumowanie wiedzy. Każdy mógł podczas tych zajęć skorzystać z okazji i wykonać zadania, których nie udało się zrealizować podczas poprzednich zajęć. Wszyscy wytrwali i najpilniejsi słuchacze zostali nagrodzeni drobnymi nagrodami. 
Spotkania w parku wilanowskim odbywały się w dwóch zasadniczych formach - pierwsza pod namiotem oraz druga - jako wycieczka. Największym zainteresowaniem cieszyła się pierwsza forma, a więc zajęcia pod namiotem. Namiot ogrodowy, gdzie były ustawione stoliki z krzesełkami dla dzieci, mógł pomieścić kilkanaście osób jednocześnie. $Z$ uwagi na przedział wiekowy najmłodsze dzieci mogły atrakcyjnie spędzić czas malując, kolorując i wyklejając określone rysunki. Starsze dzieci chętnie rozwiązywały różnorodne zagadki w formie łamigłówek, krzyżówek, układanek oraz wykreślanek.

Do najbardziej lubianych zadań zaliczyć można wszelkiego typu kolorowanki i malowanki. Każde dziecko, mając określony rysunek, musiało je w odpowiedni sposób uzupełnić. Starsze dzieci mogły także wymyślone szablony wypełnić w inny sposób, np. poprzez przyklejenie do papieru różnych gatunków kasz, co zapewniało efektowne wykończenie zadania. Niektóre dzieci do wyklejanek używały na przykład przedmiotów znalezionych w parku. Wszystkie ćwiczenia wymagające użycia farb sprawiały dzieciom wiele radości. Zarówno odbijanie stempli wykonanych z liści na papierze, czy malowanie różnych wzorów na twarzy specjalnymi farbami.

Dzieci chodzące do starszych klas chętnie rozwiązywały zagadki i wszelkiego typu rebusy. Zainteresowaniem cieszyły się krzyżówki, do których hasła zamiast pytań tworzyły obrazki różnorodnych gatunków roślin, czy zwierząt. Również pewną ciekawość wzbudzały wykreślanki. Często sprawiały one dzieciom trudności, gdyż wiele z nazw i określeń ze świata przyrody spotykały po raz pierwszy, dzięki czemu mogły się nauczyć czegoś nowego.

Dzieci chętnie brały udział we wszystkich zabawach zręcznościowych. Niektóre $z$ zabaw wymagaly już pewnych umiejętności manualnych takich jak szycie. Jednym z ćwiczeń było własnoręczne wykonanie maskotki. Dzieci musiały według wzoru najpierw powycinać materiał, a później wypchać i zszyć pluszowe ptaki. Do wyboru były dwa gatunki: czapla siwa oraz dzięcioł zielony. Mniej pracochłonnym, lecz sprawiającym również dużo radości, było konstruowanie własnych drzewek. Dzieci do przygotowanych gałązek tworzących małe drzewo musiały dokleić liście, które także własnoręcznie wykonywały z różnych materiałów. Najmłodszym uczestnikom spodobała się jedna $z$ bardziej efektownych zabaw, jaką okazało się filtrowanie zabrudzonej wody. Dzieci mogły samodzielnie wykonać filtr do wody, poznać zasady jego działania oraz przekonać się o skutecznym jego zastosowaniu. Dziewczynki natomiast bardzo polubiły ćwiczenie wymagające wykonania kwiatów z papieru.

Wszystkim zabawom w namiocie towarzyszyły prezentacje multimedialne poświęcone tematowi spotkania. Znajdowały się w nich efektowne zdjęcia poszczególnych składników przyrody, a dla starszych osób - różne ciekawostki ich dotyczące. Każda prezentacja miała za cel nie tylko ukazanie typowych gatunków czy procesów przyrodniczych zachodzących w parku wilanowskim, ale także ich wytlumaczenie. 
W programie edukacyjnym zostały wykorzystane także inne nowoczesne środki dydaktyczne, takie jak lornetki i lupy. Przydatne były mikroskopy, dzięki którym dzieci mogły oglądać ciekawe preparaty, a także starać się wykonać własne. Młodsze dzieci mogły używać stetoskopu do osłuchiwania płynących soków w drzewach. Natomiast starsze przeprowadzały badania $\mathrm{pH}$ przygotowanych wcześniej preparatów.

Drugą formą realizacji programu „badacze przyrody” były wycieczki. Podczas nich wszyscy chętni spacerowicze mogli się dowiedzieć o wielu ciekawostkach występujących na terenie Wilanowa. 『ą formą zainteresowane były starsze osoby, które miały wiele pytań i chciały uzyskać konkretne informacje. Każdą wycieczkę oprowadzał przewodnik, który odpowiadał na zadawane pytania. Najchętniej z możliwości oprowadzenia po parku korzystały całe rodziny. Również zainteresowanie wycieczkami było wśród grup zorganizowanych odwiedzających pałac i przy okazji park wilanowski.

\section{Ocena praktycznej edukacji ekologicznej}

Podczas realizacji programu edukacyjnego $\mathrm{w}$ Wilanowie przeprowadzono ankiety wśród dorosłych osób. Na pytanie: co Państwa skłoniło do przyjścia do Parku? Jako przyczynę wizyty wskazano na ladną pogodę $43 \%$, Park Wilanowski $33,3 \%$, głównym celem wizyty był Pałac 9,7 \%, natomiast na zajęcia programu „badacze przyrody” wskazało 40,9\%. Na pytanie: czy są Państwo zainteresowani tematyką przyrodniczą Parku Wilanowskiego? - ankietowani wskazali odpowiedź twierdzącą w $97.8 \%$. Zatem, wynika z tego, iż osoby odwiedzające Park Wilanowski są zainteresowane kwestiami przyrodniczymi.

Ważnym zagadnieniem staje się świadomość ekologiczna. Sama wiedza nie oznacza, że dbamy o środowisko. Przyroda może przecież ulec zniszczeniu nawet wtedy, gdy wszyscy ludzie dobrze ja poznaja. Wiedza jest oczywiście potrzebna do uświadomienia negatywnego wplywu człowieka na przyrodę. Jej zdobycie powinno prowadzić do decyzji podjęcia przez każdego człowieka odpowiednich działań stosownie do swoich możliwości, aby oddzialywanie na środowisko zminimalizować. Dopiero dwa wspomniane powyżej czynniki: wiedza i oparte na niej działanie, moga przynieść wymienione efekty. Dlatego też w ksztaltowaniu postawy, która moglibyśmy określić jako ekologiczna, najbardziej wartościowe sa te projekty edukacyjne, które uwzględniają oba wspomniane elementy ${ }^{12}$. Należy zwrócić uwagę na kwestię stosowanych metod, które powinny być metodami aktywizującymi.

12 A. PawŁowski. Edukacja ekologiczna w rodzinie - uwagi do dyskusji, w: (red. J. W. Czartoszewski), Etyka środowiskowa wyzwaniem XXI wieku. Chrześcijaństwo i edukacja ekologiczna t. 3, Warszawa 2002, s. 193. 
W programie edukacyjnym „badacze przyrody” wykorzystano wiele środków i metod, aby zachęcić do udziału jak największej liczby osób i przekazać treści wynikające z założeń tego programu. Wśród ankiet przeprowadzonych podczas zajęć znalazły się także następujące pytania. Pierwsze: czy spotkanie było atrakcyjne dla Państwa? Aż 97.8 \% udzieliło pozytywnej odpowiedzi. Kolejnym pytaniem było: czy przyjdą Państwo na następne spotkanie? \wierdząco odpowiedziało 95.7 \% osób. Jednak osoby, które odpowiedziały negatywnie wskazywały na dalekie miejsce zamieszkania i brak możliwości na cykliczne uczestnictwo w zajęciach. Wynika $z$ tego, że przez atrakcyjne spotkanie można zachęcić spacerowiczów do poszerzania swojej wiedzy.

Edukacja ekologiczna ponadto wymaga jak najczęstszego kontaktu z przyrodą. Jest ona najbardziej efektywna, gdy łączy się z praktycznym działaniem. Kazdy sukces, osiagnięty w praktycznym działaniu, ma z kolei wielkie znaczenie motywacyjne ${ }^{13}$. Prócz motywacji do zdobywania wiedzy o wszystkich aspektach przyrody, należy zwrócić uwagę na poczucie moralnej odpowiedzialności za stan przyrody ${ }^{14}$. \ak, by wykształcić postawy proekologiczne, które będą nastawione na chęć udziału społeczeństwa w procesach aktywnej ochrony przyrody. 区ak zdefiniowane cele i rozumienie edukacji i jest zbieżne z przygotowaniem młodzieży do ekorozwoju, czyli do prowadzenia gospodarki zgodnej z zasadami ekologii ${ }^{15}$. Zatem proces edukacji ma doprowadzić do zrozumienia jego zasad, celów $i$ widzenia konieczności takiego właśnie ukierunkowania polityki państwa ${ }^{16}$. Powinna zatem nastąpić zmiana podejścia do edukacji ekologicznej.

Nowoczesna edukacja ekologiczna nie może ograniczać się jedynie do prezentowania przyrody, ale także powinna wykorzystywać i łączyć wiedzę z innych obszarów. Edukacja środowiskowa jako dyscyplina wychodzaca od powszechnej edukacji, aby nie powielać niedoskonałości innych dyscyplin naukowych, które potrzebowaly odpowiedniego czasu, doświadczeń i nakładu środków, wymaga nowej perspektywy, z która wiaże się zmiana metod nauczania. (...) a także poszukiwanie coraz doskonalszych celów i form edukacji - nadawanie jej sensu i prawomocności ${ }^{17}$.

13 W. Borkowski, Terenowa edukacja ekologiczna, w: (red. J. Leśniewska, J. W. Czartoszewski), Edukacja w naturze, czyli jak pokochać, poznać, zrozumieć i chronić przyrodę. Chrześcijaństwo i edukacja ekologiczna, t. 2, Warszawa 2002, s. 40.

14 Zob. D. Szarzala. Edukacja ekologiczna w aspekcie etyki środowiskowej, w: (red. J. W. Czartoszewski), Etyka środowiskowa wyzwaniem XXI wieku. Chrześcijaństwo i edukacja ekologiczna, t. 3, Warszawa 2002, 115-131.

15 D. Cichy, Swiadomość ekologiczna młodzieży szkolnej, w: (red. J. M. Dołęga, J. Sandner), Swiadomość i edukacja ekologiczna, Warszawa 1998, s. 9.

16 K. SMOLAK. Edukacja wśród przyrody, w: (red. J. W. Czartoszewski), Edukacja ekologiczna na progu XXI wieku, stan, możliwości, programy. Chrześcijaństwo i edukacja ekologiczna, t. 1, Warszawa 2001, s. 31.

17 Z. Czaja, P. Bajon. Alternatywna edukacja ekologiczna - ogólne zatożenia, w: (red. J. W. Czartoszewski), Edukacja ekologiczna na progu XXI wieku, stan, możliwości, programy. Chrześcijaństwo i edukacja ekologiczna, t. 1, Warszawa 2001, s. 37. 


\title{
5. Wnioski
}

Aby edukacja ekologiczna była skuteczna, powinno się sięgać po wszelkie dostępne formy edukacji. Wydaje się, iż najlepszą i najbardziej efektywną jest edukacja w naturze. Podczas procesu edukacji należy planować spotkanie w taki sposób, by uczyć kompleksowego podejścia do przyrody. Całe wychowanie powinno kształtować wśród uczniów świadomość ekologiczną oraz wzbudzać odpowiedzialność za świat przyrody.

Zaplanowane podczas programu „badacze przyrody” spotkania wskazują, iż można ludzi zachęcić do korzystania z zajęć edukacyjnych. Niezależnie od wieku, każdy człowiek chce zdobywać wiedzę, czy też sobie odświeżyć i utrwalić własne wiadomości. Najlepszym sposobem może być zabawa. Atrakcyjnie przygotowane zajęcia przyciągaly uwagę zarówno mieszkańców Warszawy, jaki i wielu osób przyjezdnych, które tylko na chwilę bawily się w ramach programu „badacze przyrody". Wskaźnikiem, który może świadczyć o spełnieniu celów postawionych przed tym przedsięwzięciem, może być obecność rodzin, które cyklicznie przychodziły na kolejne spotkania, a także turystów uczestniczących tylko w niektórych spotkaniach i wyrażali swe zadowolenie.

\section{Practical possibilities of ecological education in the context of "Nature explorers" programme}

\author{
SUMMARY
}

The aim of this article is to introduce ecological education in practical use. Many expectations are connected with informal education. These expectations are often met by organizing educational actions. The article describes an educational programme called "Nature explorers", which was realized by Wilanow Palace Museum in cooperation with University of Cardinal Stefan Wyszynski in Warsaw. The article also presents conclusions and opinion about possibilities of accomplish the tasks that are set before ecological education after carrying the educational programme. 